\title{
A Legal Assistance In Criminal Action Trial Process
}

\author{
Akhmad Mufasirin*) and Aryani Witasari**) \\ ${ }^{*}$ Advocate, E-mail: mufasirin82@gmail.com \\ ${ }^{* *}$ Faculty of Law, Universitas Islam Sultan Agung Semarang
}

\begin{abstract}
The purpose of this study was to analyze the form of legal aid in the criminal trial process. To analyze the forms of legal assistance provided by the Legal Aid Institute for victims. To analyze the obstacles to legal aid in the criminal trial process and its solutions. The method used by the researcher is a sociological juridical approach and the specifications in this study include analytical descriptive. Based on the results of the research that the form of legal assistance in the criminal trial process is to accompany the suspect/defendant at every level of examination, especially the level of prosecution and trial of criminal acts, so that human rights are guaranteed, during and after the trial and seek diversion of criminal cases so that the perpetrators of criminal acts get their rights. The forms of legal assistance that can be provided to victims by $\mathrm{LBH}$, in the criminal justice process, start from assistance carried out when the victim starts reporting the case to the police until the case is decided in court. Constraints: In practice, the provision of legal aid that has been applied is only limited to the provision of legal aid as mandated by Article 56 of the Criminal Procedure Code. In the appointment of legal counsel for the Defendant based on the mandate of Article 56 of the KUHAP in the event that the Defendant is incapacitated who is threatened with a sentence of five years or more who does not have his own legal advisor, Judges often make stipulations on the appointment of legal counsel without knowing in advance whether the defendant is economically capable or not. Solution: Provide information on Posbakum services for the Defendant in the District Court. In this case, this can be done by placing an information board on the Posbakum service in front of the District Court Detainee or by providing a pamphlet containing information on the Posbakum service in the detention room.

Keywords: Legal Aid; Trial; Corruption Crime.
\end{abstract}

\section{Introduction}

The 1945 Constitution of the Republic of Indonesia (hereinafter referred to as the 1945 Constitution of the Republic of Indonesia) stipulates that Indonesia is a constitutional state. In a state of law (rechsstaat), the state is on an equal footing with the individual. Individual rights are always protected by law, where the state guarantees equality before the law and recognizes and protects human rights. Human rights are a set of rights that are inherent in the nature and existence of humans as creatures of God Almighty and are His gift that must be respected, upheld and protected by the state, government and everyone for the sake of honor and protection of human dignity. ${ }^{1}$

The Indonesian legal system and the 1945 Constitution have guaranteed equal rights of its citizens before the law (equality before the law), but not only

${ }^{1}$ Bisri, Ilham, 2004, Sistem Hukum Indonesia, Rajawali pers, Jatinangor, p. 40. 
that equality before the law must also be accompanied by equal treatment. ${ }^{2}$ Legal aid is here to make people aware of their rights as legal subjects, as well as to uphold the values of human rights for the creation of a state of law (rechtstaat). As a democratic legal state that upholds human rights, everyone has the right to receive equal treatment and protection by the laws and regulations in force in Indonesia. Therefore, for every criminal act or alleged violation of the law, the suspect is also entitled to receive the necessary legal assistance in accordance with the principle of the rule of law. The principle of the rule of law contains the principle of "equality before the law" and "presumption of innocence" or often called the principle of presumption of innocence. ${ }^{3}$

In maintaining public security and order, the existence of civil society organizations must not be separated from how the police can monitor the activities of a group of people, it is not allowed to hold community organization activities that have an impact on security and disturbance of public order, which in turn will result in violations of the law. ${ }^{4}$

Based on the problems above, the objectives of this study are as follows: To analyze the form of legal aid in the criminal trial process. To analyze the forms of legal assistance provided by the Legal Aid Institute for victims. To analyze the obstacles to legal aid in the criminal trial process and their solutions

\section{Research Methods}

Judging from the research approach, this research uses a sociological juridical approach. The sociological juridical approach is research that focuses on individual or community behavior in relation to the law. ${ }^{5}$ This research will use a descriptive type of research. Descriptive research aims to accurately describe the characteristics of a particular individual, condition, symptom or group or to determine the spread of a symptom or to determine whether or not there is a relationship between a symptom and other symptoms in society. ${ }^{6}$

\section{Results and Discussion}

\subsection{The Form of Legal Aid in Criminal Trial Process}

Judicial power as an instrument of the State stands alone beside and parallel to the other two state instruments, namely executive power and legislative power and therefore judicial power is free from these two state instruments. The guarantees given to a judge are very important in order to achieve the legal objectives in this case criminal law within the scope of the criminal justice system.

\footnotetext{
2 Winarta, Frans Hendra, 2010, Bantuan Hukum Di Indonesia, Elex Media Komputindo, Jakarta (then abbreviated as Winarta, Frans Hendra I), p.101.

${ }^{3}$ Djoko Prakoso. 1985, Kedudukan Justisiabel di Dalam KUHAP. Ghalia Indonesia, Jakarta, p. 28

${ }^{4}$ Sunardi and Sri Kusriyah, Implementation Of The Police Role In Doing Control And Law Enforcement Against Police In Area Community Organization Indramayu Associated With Act No. 17 In 2013 Jo. Act No. 16 2018, Jurnal Daulat Hukum Volume 1 Issue 2, June 2018 ISSN: 2614-560X

${ }_{5}^{5}$ Marzuki, Peter Mahmud. 2005. Penelitian Hukum. Kencana Penada Media Group, Jakarta, p. 128

${ }^{6}$ Beni Ahmad Saebani, 2008, Metode Penelitian Hukum, Pustaka Setia, Bandung, p. 100-101
} 
Specifically in providing legal assistance in criminal cases at the stage of examining defendants in court, apart from referring to the Criminal Procedure Code and Act No. 48 of 2009 concerning Judicial Powers, guidelines have been issued for courts in the implementation of legal aid as regulated in Supreme Court Regulation Number 1 of 2014 concerning Guidelines for Providing Legal Services for Poor People in Courts. Perma number 1 of 2014 replaces the Circular Letter of the Supreme Court (SEMA) Number 10 of 2010 concerning Guidelines for Providing Legal Aid.

The provision of legal assistance in criminal cases is contained in Act No. 8 of 1981 concerning the Criminal Procedure Code. According to the Criminal Procedure Code, legal aid is an activity to defend a suspect or defendant at every level of examination from the investigation stage to the stage of examining cases in court carried out by legal advisors. Legal Aid is broadly defined as an effort to help disadvantaged groups in the legal field. From a subjective point of view, legal aid is an effort given to protect the interests of someone who is going to or is having proceedings before the court. Meanwhile, from an objective point of view, legal aid departs from the goals or objectives to be achieved for the implementation of the judiciary itself. ${ }^{7}$

Act No. 16 of 2011 concerning Legal Aid regulates the definition of Legal Aid, Legal Aid Recipients, Legal Aid Providers, rights and obligations of Legal Aid Recipients, requirements and procedures for applying for Legal Aid, funding, prohibitions, and criminal provisions. The Law on Legal Aid exists because the Right to Legal Aid has been universally accepted as guaranteed in the International Covenant on Civil and Political Rights (ICCPR). Articles 16 and 26 of the ICCPR guarantee that everyone has the right to legal protection and must be avoided from all forms of discrimination.

Likewise, if we want to measure the effectiveness of the role of legal aid agencies, if law enforcers and the community obey the laws and regulations that have been set regarding the importance of assistance provided by legal aid agencies in guarding and dealing with someone who is in conflict with the law, then in addition to the effectiveness of the law, properly, the effectiveness of the role of legal aid institutions will also be good so that the rights and protection of people in conflict with the law will be fulfilled. ${ }^{8}$

Form Legal assistance in the criminal trial process is to accompany the suspect/defendant at every level of examination, especially at the level of prosecution and trial of criminal acts, so that human rights are guaranteed, during and after the trial and seek diversion of criminal cases so that the perpetrators of criminal acts get the rights.

According to the author, form Legal aid in the criminal trial process is analyzed using the theory of legal protection that legal protection is to provide protection for human rights that are harmed by others and that protection is given to the community so that they can enjoy all the rights granted by law. The law aims

${ }^{7}$ Bambang Sunggono dan Arie Harianto. 2009, Bantuan Hukum Dan HAM: Mandar Maju. Jakarta. p. 125

${ }^{8}$ Ahmad Muntolib, Sri Endah Wahyuningsih, Peran Bantuan Hukum Dalam Proses Peradilan Pidana Di Kabupaten Blora , Jurnal Hukum Khaira Ummah Vol. 12. No. 3 September 3, 2017 
to coordinate and integrate various interests in society because in a traffic of interests, protection of certain interests can only be done by limiting the interests of other parties. It can be concluded that legal protection is protecting the human rights of victims who have been violated or harmed by others, and so that the rights of victims can be restored.

Form legal aid in the criminal trial process is analyzed using legal theory in an Islamic perspective that the legal istinbat method, through ushul fiqh can help humans in knowing God's law according to their limits. It becomes a bridge between God's will and the capture of human understanding, this is where the interpretation of meaning becomes urgent and needed.

\subsection{Forms of legal assistance provided by the Legal Aid Institute for victims}

Legal aid is part of the legal profession (advocate) that has been pioneered since Roman times and introduced in the United States at the end of the nineteenth century. Even so, the public and even the legal profession (advocates) still have the wrong perception about legal aid.

The LBH was founded with the initial concept of protecting the community from legal oppression that often befalls them. This concept is then stated in the Articles of Association of LBH which states that the objectives of LBH are:

- Providing legal services to the poor

- Develop and increase people's legal awareness, especially regarding their rights as legal subjects

- Seek legal changes and improvements to meet the new needs of a developing society. ${ }^{9}$

Forms of legal assistance that can be provided to victims by: LBHIn the criminal justice process, starting from the assistance carried out when the victim starts reporting the case to the police until the case is sentenced in court.

According to the author, the forms of legal assistance provided by the Legal Aid Institute for victims are analyzed using the theory of legal protection that legal protection can also be interpreted as an action or effort to protect the public from arbitrary actions by authorities that are not in accordance with the rule of law, to create order and tranquility so as to enable humans to enjoy their dignity as human beings.

The forms of legal assistance provided by the Legal Aid Institute for victims are analyzed using legal theory according to an Islamic perspective that the ushul fiqh scholars in doing istibath the approach developed is an approach through linguistic rules and an approach through the meaning or purpose of sharia (maqashid al sharia). The linguistic approach is carried out because the study is related to the text of the Shari'a, while the objective approach to the Shari'a is because the study is related to the will of the syar'i which of course can only be known through the study of maqashid al sharia.

\footnotetext{
9 Binziad Kadafi, et.all, 2002, Advokat Indonesia Mencari Legitimasi Studi Tentang Tanggung Jawab Profesi Hukum di Indonesia, Pusat Studi Hukum \&Kebijakan Indonesia, Jakarta, p.163.
} 


\subsection{Obstacles to legal aid in criminal proceedings and their solutions}

Indonesia which adheres to an integrated law enforcement system (Integrated Criminal Justice System) which is the legal spirit of the Criminal Procedure Code. This integration is philosophically an instrument to realize the national goal of the Indonesian nation which has been formulated by The Founding Fathers in the 1945 Constitution, namely protecting the community (social defense) in order to achieve social welfare (public welfare). ${ }^{10}$ The criminal justice system is a crime control system consisting of police institutions. Prosecutors, courts and convicts. ${ }^{11}$ It was also stated that the criminal justice system is a system in a society to deal with crime. Laptara said, "the criminal justice system has four functional components that are always related and coordinated, which have a single unified perception and the same goal, namely efforts to tackle crime. ${ }^{12}$

In the current Criminal Code, the punishment is regulated in Chapter II Articles 10-43. Based on Article 10 of the Criminal Code, the types of crimes are first, the principal punishment, which consists of the death penalty, imprisonment, imprisonment, fines, and imprisonment. ${ }^{13}$

Law enforcement continues, but the post-reform legal paradigm shift is a phenomenon that greatly influences the political arena and constitutional life in Indonesia. But on the other hand, the law has not been fully capable of satisfying the thirst in the midst of the thirst for justice and the welfare of the people. There are still many legal cases that have not been completely resolved so that it affects people's trust in law enforcement. Such a phenomenon has caused a lot of debate, especially regarding the relevance of law enforcement to the values of social justice and public welfare. ${ }^{14}$ With these conditions, it is necessary to increase the role of law enforcement in law enforcement. ${ }^{15}$

Basically someone has the right to get legal assistance, for example being accompanied by an advocate has started since a criminal case, for example someone wants to make a complaint report to the Police for a crime committed by someone else to him, then in this case can ask for the help of an advocate to accompany him to the Police office. Or, for example, if someone is reported to have committed a crime and is then called by the police as a reported person or witness, he can also be accompanied by an advocate. ${ }^{16}$

\footnotetext{
${ }^{10}$ Romli Atmasasmita, 2002. Sistem Peradilan Pidana; Perspektif Eksistensialisme dan bilisionisme, Rineka Cipta, Bandung, p. 9-10.

${ }^{11}$ Mardjono Reksodiputro, 1993. Sistem Peradilan Pidana Indonesia (Melihat Kepada Kejahatan Dan Penegakan Hukum Dalam Batas-Batas Toleransi), Faculty of Law, University of Indonesia, p. 1 ${ }^{12}$ J.W. Lapatra, 1078. Analyzing the Criminal Justice Systems, Massachusetts: Lexinton Books, p. 86. ${ }^{13}$ Hulman Siregar, Rumusan Pidana Dan Pemidanaan Tindak pidana Korupsi Yang Merugikan Keuangan Negara Serta Permasalaan Dalam Penerapannya, Jurnal Daulat Hukum Vol. 1. No. 1 March, 2018 ISSN: 2614-560X, Unissula

${ }^{14}$ Gunarto, Agenda Penegakan Hukum dan Relevansinya Bagi Pembangunan Bangsa, Jurnal Pembaharuan Hukum Volume I, No.1, January-April 2014, p. 1.

${ }^{15}$ Setyo Langgeng, Peran Advokat Sebagai Penegak Hukum Dalam Mendukung Terwujudnya Sistem Peradilan Pidana Terpadu Dalam Penegakan Hukum Pidana Di Indonesia, Jurnal Daulat Hukum Volume 1 No. 1 March, 2018 : 138 - 156, Unissula

16 https://seniorkampus.blogspot.com/2014/07/ Hukum-acara-pidana-bantuan- Hukum.html, accessed on April 1, 2021 at 20:28 wib
} 
Obstacles to legal aid in the trial process for criminal acts are: in practice the provision of legal aid that has been applied is only limited to the provision of legal aid mandated by article 56 of the Criminal Procedure Code. In the appointment of legal counsel for the Defendant based on the mandate of Article 56 of the Criminal Procedure Code in the event that the Defendant is incapacitated who is threatened with a sentence of five years or more who does not have his own legal advisor, the Judge often makes a determination on the appointment of a legal advisor without first knowing whether the defendant is economically capable or not. This is known based on the report on the appointment of cases handled by Posbakum.

The solution to overcome obstacles to legal aid in the criminal trial process is: providing information on Posbakum services for the Defendant in Court. Before giving the Appointment of Legal Counsel, firstly to ensure whether the Defendant is capable or not, which is indicated by a certificate of incapacity.

According to the author, the obstacles to legal aid in the criminal trial process and the solutions are analyzed using the theory of legal certainty that legal certainty is a guarantee of law that contains justice. Norms that promote justice must really function as rules to be obeyed.

Constraints of legal aid in the trial process of criminal acts and their solutions are analyzed using legal theory in an Islamic perspective that Islamic legal thought can be a necessity, but as a method of interpreting $t a{ }^{\prime} w i l$ it is closer to maintaining faith norms against the basics of religious belief. $\mathrm{Ta}^{\prime}$ wil is also a good method to dispel doubts because ta'wil is not a tool to invalidate faith or empty religious texts from the spirit of religion and this is next to hermeneutics. The application of hermeneutics in Islamic law will encounter many obstacles, because in Islamic law there are problems that have been accepted axioms without the need for other interpretations and understandings.

\section{Closing}

Based on the results of research and discussion in the previous chapter, it can be concluded that: Form Legal assistance in the criminal trial process is to accompany the suspect/defendant at every level of examination, especially at the level of prosecution and criminal justice. The forms of legal assistance that can be provided to victims in the criminal justice process start from the assistance provided when the victim begins to report the case to the police until the case is sentenced in the district court. In practice, the provision of legal aid that has been applied is limited to the provision of legal aid mandated by Article 56 of the Criminal Procedure Code. In the appointment of legal counsel for the Defendant based on the mandate of Article 56 of the Criminal Procedure Code, in the event that the Defendant is incapacitated, he is threatened with a sentence of five years or more who does not have his own legal advisor. The solution is to provide information on Posbakum services for the defendant in court. Before giving the Appointment of Legal Counsel, firstly to ensure whether the Defendant is capable or not, which is indicated by a certificate of incapacity. 


\section{References}

\section{Journal}

[1] Ahmad Muntolib, Sri Endah Wahyuningsih, Peran Bantuan Hukum Dalam Proses Peradilan Pidana Di Kabupaten Blora, Jurnal Hukum Khaira Ummah Vol. 12. No. 3 September 2017

[2] Gunarto, Agenda Penegakan Hukum dan Relevansinya Bagi Pembangunan Bangsa, Jurnal Pembaharuan Hukum Volume I, No.1, January-April 2014,

[3] Hulman Siregar, Rumusan Pidana Dan Pemidanaan Tindak pidana Korupsi Yang Merugikan Keuangan Negara Serta Permasalaan Dalam Penerapannya, Jurnal Daulat Hukum Vol. 1. No. 1 March 2018 ISSN: 2614-560X, Unissula

[4] Setyo Langgeng, Peran Advokat Sebagai Penegak Hukum Dalam Mendukung Terwujudnya Sistem Peradilan Pidana Terpadu Dalam Penegakan Hukum Pidana Di Indonesia, Jurnal Daulat Hukum Volume 1 No. 1 March 2018 : 138 156, Unissula

[5] Sunardi and Sri Kusriyah, Implementation Of The Police Role In Doing Control And Law Enforcement Against Police In Area Community Organization Indramayu Associated With Act No. 17 In 2013 Jo. Act No. 16 2018, Jurnal Daulat Hukum Volume 1 Issue 2, June 2018 ISSN: 2614-560X

\section{Buku}

[1] Bambang Sunggono dan Arie Harianto. 2009, Bantuan Hukum Dan HAM: Mandar Maju. Jakarta

[2] Beni Ahmad Saebani, 2008, Metode Penelitian Hukum, Pustaka Setia, Bandung,

[3] Binziad Kadafi, et.all, 2002, Advokat Indonesia Mencari Legitimasi Studi Tentang Tanggung Jawab Profesi Hukum di Indonesia, Pusat Studi Hukum \& Kebijakan Indonesia, Jakarta

[4] Bisri, Ilham, 2004, Sistem Hukum Indonesia, Rajawali pers, Jatinangor

[5] Djoko Prakoso. 1985, Kedudukan Justisiabel di Dalam KUHAP. Ghalia Indonesia, Jakarta

[6] J.W. Lapatra, 1078. Analyzing the Criminal Justice Systems, Massachusetts: Lexinton Books

[7] Mardjono Reksodiputro, 1993. Sistem Peradilan Pidana Indonesia (Melihat Kepada Kejahatan Dan Penegakan Hukum Dalam Batas-Batas Toleransi), Faculty of Law, Unversity of Indonesia

[8] Marzuki, Peter Mahmud. 2005. Penelitian Hukum. Kencana Penada Media Group, Jakarta

[9] Romli Atmasasmita, 2002. Sistem Peradilan Pidana; Perspektif Eksistensialisme dan bilisionisme, Rineka Cipta, Bandung

[10] Winarta, Frans Hendra, 2010, Bantuan Hukum Di Indonesia, Elex Media Komputindo, Jakarta.

\section{Internet}

https://seniorkampus.blogspot.com/2014/07/hukum-acara-pidana-bantuanhukum.html, accessed on 1 April 2021 at $20.28 \mathrm{wib}$ 